\title{
Copper availability and selective microbiological properties of an intensively cultivated ultisol in Nuwara Eliya
}

\author{
W.S. Dandeniya and R.M.C.P. Rajapaksha* \\ Department of Soil Science, Faculty of Agriculture, University of Peradeniya, Peradeniya.
}

Revised: 04 April 2008 ; Accepted: 11 August 2008

\begin{abstract}
A study was undertaken to assess the effect of copper on microbiological properties of intensively cultivated vegetable fields at Nuwara Eliya. Soil samples were collected from six cultivated fields and an undisturbed forest were assessed for $\mathrm{pH}$, total and DTPA extractable $\mathrm{Cu}$, biomass nitrogen $(\mathrm{BN})$ and substrate induced respiration (SIR). Total and $\mathrm{Cu}$-resistant bacteria were enumerated using four agar media. Soil pH of experimental soils ranged from 4.44 to 5.44 . Organic C content in cultivated soils varied from 1.8 to $3.3 \%$ and it was $6.8 \%$ in forest soil. Total and DTPA extractable $\mathrm{Cu}$ contents varied from 14.4 to $25.6 \mathrm{mg} \mathrm{kg}^{-1}$ and 1.2 to $4.5 \mathrm{mg} \mathrm{kg}^{-1}$, respectively. Forest soil showed the highest SIR (46 $\mu \mathrm{g} \mathrm{CO}_{2} \mathrm{~g}^{-1}$ soil $\left.\mathrm{h}^{-1}\right)$ and $\mathrm{BN}\left(267 \mu \mathrm{g} \mathrm{N} \mathrm{g}^{-1}\right.$ soil). The highest $\mathrm{Cu}$-resistant bacterial population was $0.43 \%$ of the total population reported for the forest. Building up of $\mathrm{Cu}$ and increasing of population of $\mathrm{Cu}$-resistant bacteria was not evident due to cultivation. The percentage of $\mathrm{Cu}$-resistant bacteria correlated positively with DTPA extractable $\mathrm{Cu}(\mathrm{R}=0.49)$ suggesting that threshold $\mathrm{Cu}$ levels for bacterial growth in experimental soils remain within the range of extractable $\mathrm{Cu}$ concentrations reported. This relationship was influenced by soil organic $\mathrm{C}$ content and $\mathrm{pH}$. Tryptic soy agar (TSA) medium produced higher percentages of $\mathrm{Cu}$-resistant bacteria for both forest and cultivated soils. Those percentages showed linear relationships with total $\mathrm{Cu}\left(\mathrm{r}^{2}=0.95\right)$ and percentage of DTPA extractable $\mathrm{Cu}\left(\mathrm{r}^{2}=0.94\right)$ indicating suitability of the TSA medium to enumerate $\mathrm{Cu}$-resistant bacteria.
\end{abstract}

Keywords: Bacteria, copper, cultivated ecosystems, organic carbon, $\mathrm{pH}$.

\section{INTRODUCTION}

Accumulation of heavy metals in soil is a common external disturbance which affects soil quality. Copper is known to accumulate in soils of intensively cultivated agricultural systems applied with high doses of fungicide and poultry manure ${ }^{1,2}$. Copper exists in the soil environment in different forms; exchangeable, sorbed, organically bound, precipitated, and residual ${ }^{3-7}$. The fraction of $\mathrm{Cu}$ in soil solution is governed directly by the quality and the quantity of organic matter, clay type, amount of $\mathrm{Fe}$ and $\mathrm{Al}$ oxides in soil and indirectly by soil $\mathrm{pH}^{3,5,8,9}$. Copper speciation thus varied among soils with different soil characteristics ${ }^{6,10}$.

Metals in the soil environment are beneficial for microbial growth but detrimental when their concentrations reach toxic levels. In general, metal stress in agricultural soils is known to reduce the size and the activity of microbial biomass and alter the composition of microbial community structures ${ }^{11,12}$. A range of microbiological properties had been suggested as indicators of metal stress conditions in the soil environment. Examples are substrate induced respiration, ${ }^{12}$ nitrification, ${ }^{13}$ microbial biomass $^{14}$ and carbon utilization efficiency ${ }^{15}$. However, microorganisms may detoxify harmful metals through various biochemical mechanisms and develop resistance against metals to a certain degree ${ }^{12}$. This has been demonstrated for soils contaminated with metals naturally and experimentally ${ }^{14,16,17}$. Therefore, populations of heavy metal resistant bacteria and fungi have been proposed as indicators of metal pollution in natural and disturbed soil $^{12,16,18}$.

Vegetable cropping systems in Nuwara Eliya receive a large quantity of agro-chemicals throughout the growing season. Soil in this area has been classified as ultisol, which is a predominant soil order in humid tropics. These soils are characterized with low $\mathrm{pH}$ and high 1:1 type clay minerals that influence metal speciation to a greater extent. As a result, metal stressful conditions may exist in soils under vegetable cropping systems. Therefore, a study 
was undertaken to assess the variability of $\mathrm{Cu}$ fractions and microbiological properties of intensively cultivated ultisol and the possibility of developing resistance to $\mathrm{Cu}$ in bacteria. For comparison, an undisturbed forest soil, which did not receive agrochemicals, was included.

\section{METHODS AND MATERIALS}

Site description and soil sampling: The studied site located in Nuwara Eliya, is $1900 \mathrm{~m}$ above mean sea level. This area is characterized with hilly landscape and has a mean annual temperature of $16^{\circ} \mathrm{C}$ and mean annual rainfall of $2500 \mathrm{~mm}$. The soil is classified as Typic paleudults. Soil in this area is strongly acidic in reaction and kaolinite has been reported as the dominant clay mineral associated with $10 \%$ or more gibbsite ${ }^{19,20}$. Potato (Solanum tuberosum) is the main crop grown in the studied area, at least twice a year with high inputs of chemical fertilizers, cattle and poultry manures and fungicides. Soil samples were collected from a 0-10 $\mathrm{cm}$ depth of six fields at the harvesting stage of potato. The selected fields have been cultivated for different durations with varying management practices (Table 1). Soil samples were also collected from a virgin montane forest in the upperslope position of the same landscape. Six composite soil samples were collected from each cultivated field and forest (total of 42 samples) and stored at $4^{\circ} \mathrm{C}$ until analyzes commenced.

Soil chemical properties: Air dried and sieved soil samples were used to assess $\mathrm{pH}$, carbon and $\mathrm{Cu}$ fractions. Soil $\mathrm{pH}$ was measured by glass electrode ${ }^{21}$ in a suspension of $2 \mathrm{M} \mathrm{KCl}$ solution $(1: 2.5)$ and total organic $\mathrm{C}$ content by wet digestion ${ }^{22}$. Total $\mathrm{Cu}$ in soil was extracted by digesting $2 \mathrm{~g}$ of air dried soil in $20 \mathrm{~mL}$ of $4 \mathrm{~N}^{\mathrm{HNO}_{3}}$ solution for four hours at $80^{\circ} \mathrm{C}^{23}$. Potentially bioavailable

Table 1: The number of years of cultivation, landscape position and intensity of cultivation of selected fields

\begin{tabular}{cccc}
\hline Field & $\begin{array}{c}\text { Years of } \\
\text { cultivation }\end{array}$ & $\begin{array}{c}\text { Landscape } \\
\text { position }\end{array}$ & $\begin{array}{c}\text { Intensity of } \\
\text { cultivation }^{\text {a }}\end{array}$ \\
\hline A & $>45$ & shoulder & high \\
B & 30 & shoulder & high \\
C & 30 & footslope & high \\
D & 10 & shoulder & low \\
E & 10 & footslope & high \\
F & - & shoulder & high \\
\hline
\end{tabular}

a High intensive cultivation, refers to fields with year-round continuous cultivation, received agrochemicals frequently at a rate of exceeding the recommended levels of the Department of Agriculture, whereas low intensity refers to fields that fallowed for $1-2$ months per year and received agrochemicals at or less than the recommended dosages.
$\mathrm{Cu}$ fraction was extracted using DTPA -TEA solution (0.005 M diethylenetriaminepentaacecetic acid, $0.1 \mathrm{M}$

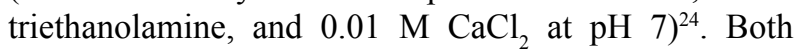
$\mathrm{Cu}$ fractions were analyzed by Atomic Absorption Spectrophotometry (Shimadzu, AA6200) with a minimum detection level of $0.01 \mathrm{ppm}$.

Soil microbiological properties: Substrate induced respiration (SIR) was determined by adding glucose to fresh soil at a rate of $200 \mu \mathrm{mol}$ glucose $\mathrm{g}^{-1}$ soil $^{25}$. Microbial biomass nitrogen $(\mathrm{BN})$ was determined using chloroform fumigation extraction method ${ }^{26}$. The extracted nitrogen forms were reduced to $\mathrm{NH}_{4}^{+}-\mathrm{N}$ and analyzed using the colorimetric method ${ }^{27}$. The populations of culturable bacteria were enumerated by plating aliquots of serial dilutions to tryptic soy agar (TSA) medium amended with $100 \mathrm{mg}$ of cycloheximide $\mathrm{L}^{-1}$. The same medium was amended with $\mathrm{CuSO}_{4}$ to achieve a final concentration of $5 \mathrm{mM}$ and used to enumerate $\mathrm{Cu}$-resistant bacteria. Plates were incubated for $3-7 \mathrm{~d}$ at $28^{\circ} \mathrm{C}$ and single colonies were counted. An attempt was also made to assess the suitability of different agar media to estimate the $\mathrm{Cu}$ resistant bacterial population. For this purpose, three additional agar media, tryptic soy broth (TSB), potato dextrose yeast-extract agar (PDYA) and peptone-glucose agar (PGA) amended with $\mathrm{CuSO}_{4}$ and cycloheximide were used. These agar plates were inoculated with soil extractants of the forest and the cultivated field ' $F$ '.

Statistical analysis: Means were compared with the Duncan mean separation test at $5 \%$ probability level for all the measured properties using SPSS (Version 13, 1998) analytical software. Means and the least significant differences at the 5\% level were calculated by one - way ANOVA for four different bacterial media in forest and field ' $F$ '. Pearson correlation coefficients were computed for selective variables.

Table 2: Soil chemical properties of cultivated and forest soils

\begin{tabular}{|c|c|c|c|c|c|}
\hline \multirow{3}{*}{ Field } & \multirow{3}{*}{ Soil pH } & \multirow{3}{*}{ Organic C } & \multicolumn{3}{|c|}{$\mathrm{Cu}$ contents } \\
\hline & & & \multirow[t]{2}{*}{ Total } & \multirow[t]{2}{*}{$\begin{array}{c}\text { DTPA } \\
\text { extractable }\end{array}$} & $\begin{array}{c}\text { DTPA } \\
\text { extractable }\end{array}$ \\
\hline & & & & & Total Cu \\
\hline & & $(\%)$ & \multicolumn{2}{|c|}{ (mg kg-1 soil) } & $(\%)$ \\
\hline A & $4.89^{\mathrm{abc}}$ & $1.8^{\mathrm{c}}$ & $25.6^{\mathrm{a}}$ & $2.2^{\mathrm{bc}}$ & $8.6^{\mathrm{b}}$ \\
\hline B & $5.44^{\mathrm{a}}$ & $2.7^{\mathrm{bc}}$ & $14.4^{b}$ & $2.0^{\mathrm{bc}}$ & $13.9^{\mathrm{b}}$ \\
\hline $\mathrm{C}$ & $5.29^{\mathrm{ab}}$ & $3.3^{\mathrm{b}}$ & $15.3^{\mathrm{b}}$ & $1.2^{\mathrm{c}}$ & $7.8^{\mathrm{b}}$ \\
\hline $\mathrm{D}$ & $4.63^{c}$ & $3.3^{\mathrm{b}}$ & $16.1^{b}$ & $1.8^{\mathrm{bc}}$ & $11.2^{\mathrm{b}}$ \\
\hline $\mathrm{E}$ & $4.78^{\mathrm{bc}}$ & $3.2^{\mathrm{b}}$ & $17.3^{\mathrm{ab}}$ & $1.9^{\mathrm{bc}}$ & $11.0^{\mathrm{b}}$ \\
\hline $\mathrm{F}$ & $4.44^{\mathrm{c}}$ & $1.8^{\mathrm{c}}$ & $18.3^{\mathrm{ab}}$ & $4.5^{\mathrm{a}}$ & $24.6^{\mathrm{a}}$ \\
\hline forest & $5.41^{\mathrm{ab}}$ & $6.8^{\mathrm{a}}$ & $19.3^{\mathrm{ab}}$ & $3.2^{\mathrm{ab}}$ & $16.6^{\mathrm{ab}}$ \\
\hline
\end{tabular}

Means $(n=6)$ given in a column followed by different letters are significantly different (subset for $\alpha=0.05$ ) 


\section{RESULTS AND DISCUSSION}

\section{Soil chemical properties}

In this study, soil from a forest located in the same landscape was chosen as the reference site. Although a forest is not the ideal reference site as the vegetation may also affect the metal status in the soil, the forest was chosen as it was not influenced by agronomic practices imposed on the cultivated fields.

All the experimental soils in the seven fields had acidic soil reaction and their mean $\mathrm{pH}$ values ranged from 4.44 to 5.44 (Table 2). The mean total organic C content in the cultivated soils varied from 1.8 to $3.3 \%$ and they were significantly lower than the forest soil $(6.8 \%)$ (Table 2). Fields 'A' and ' $F$ ' showed significantly lower C contents than fields ' $C$ ', ' $D$ ' and ' $E$ '. The total and DTPA extractable $\mathrm{Cu}$ concentrations in forest soil were 19.3 and $3.2 \mathrm{mg} \mathrm{kg}^{-1}$, respectively. The total $\mathrm{Cu}$ contents of cultivated fields were comparable to that of the forest soil (Table 2). Therefore, building up of $\mathrm{Cu}$ was not evident despite continuous cultivation with metal inputs. One possible reason would be crop uptake over the growing season. The DTPA extractable $\mathrm{Cu}$ contents of the cultivated fields varied from 1.2 to $4.5 \mathrm{mg} \mathrm{kg}^{-1}$ (Table 2). The minimum DTPA extractable and total $\mathrm{Cu}$ contents reported for the manured fields of Belgium, which are considered as contaminated, were 3.2 and $17 \mathrm{mg} \mathrm{kg}^{-1}$ soil, respectively ${ }^{16}$. The highest DTPA extractable $\mathrm{Cu}$ content observed for field ' $F$ ' ( $\left.4.5 \mathrm{mg} \mathrm{kg}^{-1}\right)$ could be attributed to its very high acidic $\mathrm{pH}$ and very low organic $\mathrm{C}$ content. The percentage of DTPA extractable $\mathrm{Cu}$ was highest in the field ' $\mathrm{F}$ ' $(24.6 \%)$ and followed by the forest soil $(16.6 \%)$ (Table 2). In addition to high total $\mathrm{Cu}$, low $\mathrm{pH}$ and low organic $\mathrm{C}$ content of field ' $\mathrm{F}$ ' may have resulted in a higher fraction of DTPA extractable $\mathrm{Cu}$.
A linear relationship was established between $\mathrm{pH}$ and percentage of DTPA extractable $\mathrm{Cu}$ for soil samples having a $\mathrm{pH}$ greater than 5 (Figure 1a), but forest soils with high organic matter content remained as outliers. In cultivated soils, high organic matter content at high $\mathrm{pH}$ condition reduce $\mathrm{Cu}^{2+}$ sorption ${ }^{4}$ and free metal activity ${ }^{14}$. However, organic $\mathrm{C}$ content did not correlate significantly with DTPA extractable $\mathrm{Cu}$ fraction of the experimental cultivated soils indicating that it was governed primarily by soil $\mathrm{pH}$.

\section{Soil microbiological properties}

Microbial biomass in soils is generally governed by the labile $\mathrm{C}$ pool $^{28}$. Forest soil showed the highest BN content (267 $\mu \mathrm{g} \mathrm{N} \mathrm{g}^{-1}$ soil) (Table 3) which is not unrealistic in comparison to BN content of $120 \mu \mathrm{g} \mathrm{g}^{-1}$ soil, recorded for a tropical forest soil with an organic $\mathrm{C}$ content of $2 \%{ }^{29}$. Ocio and Brookes ${ }^{30}$ reported that $\mathrm{BN}$ values of continuously cultivated soils, which have organic $\mathrm{C}$ contents in the range of 1.3 to $2.8 \%$, varied from 20 to $80 \mu \mathrm{g} \mathrm{N} \mathrm{g}^{-1}$ soil. In this study, fields ' $\mathrm{A}$ ' and ' $\mathrm{F}$ ' with $1.8 \%$ organic $\mathrm{C}$ content showed BN content of 173 and $58 \mu \mathrm{g} \mathrm{N} \mathrm{g}^{-1}$ soil, respectively. The former may be either due to high nitrogen availability or due to an over-estimation. In addition to significantly low organic $\mathrm{C}$ content and acidic $\mathrm{pH}$, higher $\mathrm{Cu}$ availability may be responsible (SIR) for the lowest $\mathrm{BN}$ content in the field ' $F$ '. Substrate induced respiration represents the amount of $\mathrm{C}$ in non resting micro-organisms in soil, particularly the heterotrophs that respond to added glucose readily. Boehm and Anderson ${ }^{28}$ observed high SIR and basal respiration in continuously cropped prairie soils than in crop - fallow soils. In this study, however, a significantly higher SIR was observed in the undisturbed forest which may indicate presence of a higher $\mathrm{C}$ starving population as was reflected in its high BN. Chander and Brookes ${ }^{31}$ reported a significantly higher SIR for soils with total $\mathrm{Cu}$ contents of $125 \mathrm{mg} \mathrm{kg}^{-1}$ than those with $26 \mathrm{mg} \mathrm{kg}^{-1}$.

Figure 1: Relationship between $\mathrm{pH}$ and DTPA extractable $\mathrm{Cu} \%$ in experimental soils for replicates with (a) $\mathrm{pH}>5(\mathrm{n}=12)$ and (b) $\mathrm{pH}<5(\mathrm{n}=24)$.
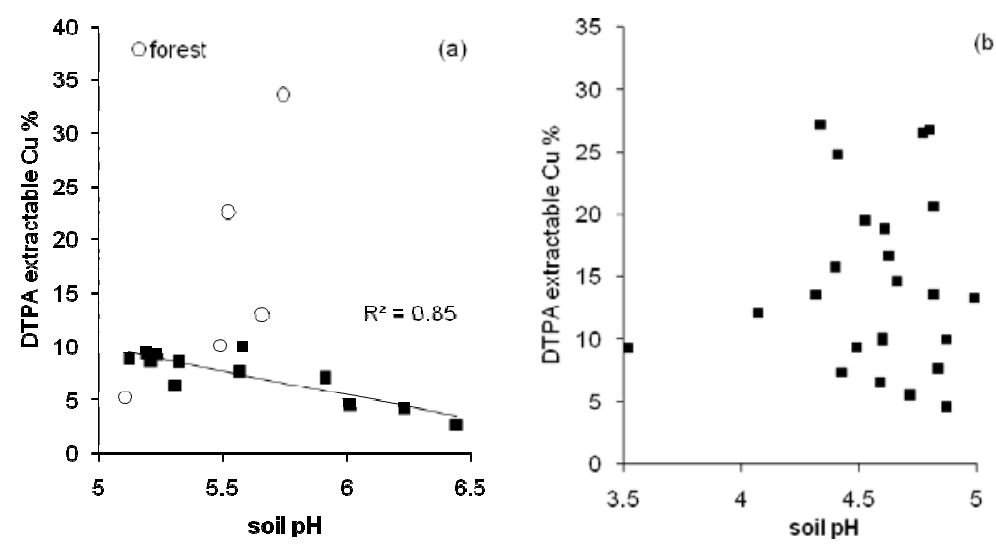
Although total $\mathrm{Cu}$ contents of studied soils were less than $26 \mathrm{mg} \mathrm{kg}^{-1}$, two soils from forest and field 'A', which had high total and available $\mathrm{Cu}$ contents resulted in a higher SIR than the rest. This observation may indicate a possible stressful condition caused by $\mathrm{Cu}$ on total microbial population in those soils. Negative correlations were reported between total $\mathrm{Cu}$ and SIR, microbial biomass, metabolic quotient, enzyme activity and bacterial biomass for soils with total $\mathrm{Cu}$ ranging from 20 to $400 \mathrm{mg} \mathrm{kg}^{-1} \mathrm{soil}^{32,33}$. Such negative correlations were not established in this study because total $\mathrm{Cu}$ contents of experimental soils varied within a narrow range and organic $\mathrm{C}$ and $\mathrm{pH}$ also differed significantly.

The culturable fraction of bacteria was lowest in the cultivated fields 'A' and ' $F$ ' and the forest soils (Table 3). Low bacterial population reported in forest may partly be due to the presence of a larger fraction of unculturable population as well as inappropriateness of the growth medium to cultivate a starving population. Lovell et al. ${ }^{34}$ also suggested that nutrient rich medium such as TSA may result in low apparent colony counts contradictorily to the high microbial activities in undisturbed soils. The lowest bacterial populations of ' $A$ ' and ' $F$ ' fields are mainly due to low organic $\mathrm{C}$ contents and acidic $\mathrm{pH}$. In addition, high DTPA extractable $\mathrm{Cu}$ may also be another reason for the affected bacterial population.

The colony counts of the Cu-resistant bacteria followed the same trend to that of the total bacterial counts (Table 3). Consequently, a positive correlation was established between $\mathrm{Cu}$ resistant bacteria and total bacterial population $(\mathrm{R}=0.83, \mathrm{p}<0.001)$. This correlation provides evidence that indigenous microbial communities of experimental soils are comprised of higher populations of Cu-resistant bacteria. Enumeration of Cu-resistant bacteria was done in agar plates having approximately $800 \mathrm{mg} \mathrm{Cu} \mathrm{L}-1$. This concentration was several hundred folds higher than the $\mathrm{Cu}$ levels experienced by bacteria in situ. Consequently, the percentage of $\mathrm{Cu}$-resistant bacteria populations remained lesser than $1 \%$ of the total bacterial population. Similar percentages have been reported previously for $\mathrm{Cu}-$ resistant bacteria extracted from manured soils in Belgium and grown on $8 \mathrm{mM} \mathrm{Cu}^{16}$. Viti et al. ${ }^{35}$ reported that a forest soil having soluble + exchangeable fractions of $\mathrm{Cu}$ comparable to those of cultivated soils $\left(1.3-4.2 \mathrm{mg} \mathrm{kg}^{-1}\right.$ soil) did not produce any colonies on $\mathrm{Cu}$ amended TSB agar plates. However, forest soil of this study showed the highest percentage of $\mathrm{Cu}$-resistant bacteria on TSA medium. Furthermore, fields ' $A$ ' and ' $F$ ' showed the lowest percentage of $\mathrm{Cu}$-resistant bacteria $(0.02 \%$ and $0.001 \%$, respectively) despite higher $\mathrm{Cu}$ fractions reported (Table 3 ). These results may suggest that the variability of the $\mathrm{Cu}$-resistant bacterial population in the studied fields is independent from the reported $\mathrm{Cu}$ fractions and perhaps length of exposure to $\mathrm{Cu}$ as well. There is evidence that $\mathrm{Cu}$-tolerant bacteria populations did not relate to soluble and exchangeable fractions of $\mathrm{Cu}$ in cultivated soils ${ }^{35}$. The authors suggest that either bacterial tolerance developed responding to acute toxicity of $\mathrm{Cu}$ immediately after applying $\mathrm{Cu}$ or to the fraction bound to a more labile humic fraction. In this study, a weak correlation was established between the percentage of $\mathrm{Cu}$-resistant bacteria and DTPA extractable $\mathrm{Cu}$ content $(\mathrm{R}=0.49, \mathrm{p}<0.03, \mathrm{n}=42)$ suggesting that the extractable fractions of $\mathrm{Cu}$ reflect the range of threshold $\mathrm{Cu}$ levels at which resistance development takes place. It has been pointed out that high variability of microbial responses to $\mathrm{Cu}$ may arise as a result of higher sensitivity of micro-organisms to soil chemical and physical properties ${ }^{14}$. In the studied cultivated soils, $\mathrm{pH}$ and organic $\mathrm{C}$ appeared as the governing factors of the populations of $\mathrm{Cu}$-resistant bacteria. These chemical properties are known to influence the fluxes of various fractions of $\mathrm{Cu}^{3,7,10}$ Correlations were also observed between the percentage of $\mathrm{Cu}$-resistant bacteria and SIR

Table 3: Biomass N, SIR and bacterial populations of experimental soils

\begin{tabular}{lccccc}
\hline Field & $\mathrm{BN}$ & $\mathrm{SIR}$ & Bacteria & $\begin{array}{c}\text { Cu-resistant } \\
\text { bacteria } \\
(\mathrm{CFU} \mathrm{X} \mathrm{10}\end{array}$ & $\begin{array}{c}\text { Cu-resistant } \\
\text { bacteria } \\
(\%)\end{array}$ \\
\hline $\mathrm{A}$ & $173^{\mathrm{ab}}$ & $32^{\mathrm{b}}$ & $87^{\mathrm{c}}$ & $8^{\mathrm{c}}$ & $0.02^{\mathrm{b}}$ \\
$\mathrm{B}$ & $168^{\mathrm{ab}}$ & $17^{\mathrm{c}}$ & $2054^{\mathrm{a}}$ & $5224^{\mathrm{a}}$ & $0.03^{\mathrm{b}}$ \\
$\mathrm{C}$ & $152^{\mathrm{ab}}$ & $9^{\mathrm{c}}$ & $843^{\mathrm{bc}}$ & $2815^{\mathrm{b}}$ & $0.09^{\mathrm{b}}$ \\
$\mathrm{D}$ & $127^{\mathrm{ab}}$ & $14^{\mathrm{c}}$ & $352^{\mathrm{bc}}$ & $2309^{\mathrm{bc}}$ & $0.15^{\mathrm{b}}$ \\
$\mathrm{E}$ & $129^{\mathrm{abc}}$ & $8^{\mathrm{c}}$ & $1164^{\mathrm{ab}}$ & $2155^{\mathrm{bc}}$ & $0.03^{\mathrm{b}}$ \\
$\mathrm{F}$ & $58^{\mathrm{b}}$ & $10^{\mathrm{c}}$ & $36^{\mathrm{c}}$ & $3^{\mathrm{c}}$ & $0.001^{\mathrm{b}}$ \\
forest & $267^{\mathrm{a}}$ & $46^{\mathrm{a}}$ & $0.6^{\mathrm{c}}$ & $11^{\mathrm{c}}$ & $0.43^{\mathrm{a}}$ \\
\hline
\end{tabular}

Means $(\mathrm{n}=6)$ given in a column followed by different letters are significantly different (subset for $\alpha=0.05$ ) 
Table 4: Total and Cu-resistant bacterial populations obtained from four growth media

\begin{tabular}{cccc}
\hline $\begin{array}{c}\text { Agar } \\
\text { medium }\end{array}$ & $\begin{array}{c}\text { Total population } \\
\text { (CFU X } 10^{7} \mathrm{~g}^{-1} \\
\text { carbon) }\end{array}$ & $\begin{array}{c}\text { Cu resistant bacteria } \\
\text { (CFU X 10 } \mathrm{g}^{-1} \\
\text { carbon) }\end{array}$ & $\begin{array}{c}\text { Cu resistant bacteria } \\
(\%)\end{array}$ \\
\hline Forest & & & $0.42^{\mathrm{a}}$ \\
TSA & $0.58^{\mathrm{b}}$ & $11^{\mathrm{b}}$ & $0.33^{\mathrm{ab}}$ \\
PDYA & $5.34^{\mathrm{ab}}$ & $150^{\mathrm{a}}$ & $0.17^{\mathrm{bc}}$ \\
PGA & $8.62^{\mathrm{a}}$ & $106^{\mathrm{a}}$ & $0.07^{\mathrm{c}}$ \\
TSB & $2.51^{\mathrm{b}}$ & $19^{\mathrm{b}}$ & \\
Field ' $\mathrm{F}$, & & & $0.0009^{\mathrm{b}}$ \\
TSA & $320^{\mathrm{b}}$ & $2^{\mathrm{b}}$ & $0.0084^{\mathrm{a}}$ \\
PDYA & $1110^{\mathrm{a}}$ & $1038^{\mathrm{a}}$ & $0.0031^{\mathrm{b}}$ \\
PGA & $1100^{\mathrm{a}}$ & $392^{\mathrm{b}}$ & $0.0007^{\mathrm{b}}$ \\
TSB & $770^{\mathrm{a}}$ & $17^{\mathrm{b}}$ & \\
\hline
\end{tabular}

Means $(n=6)$ given in a column followed by different letters are significantly different. (subset for $\alpha=0.05$ )
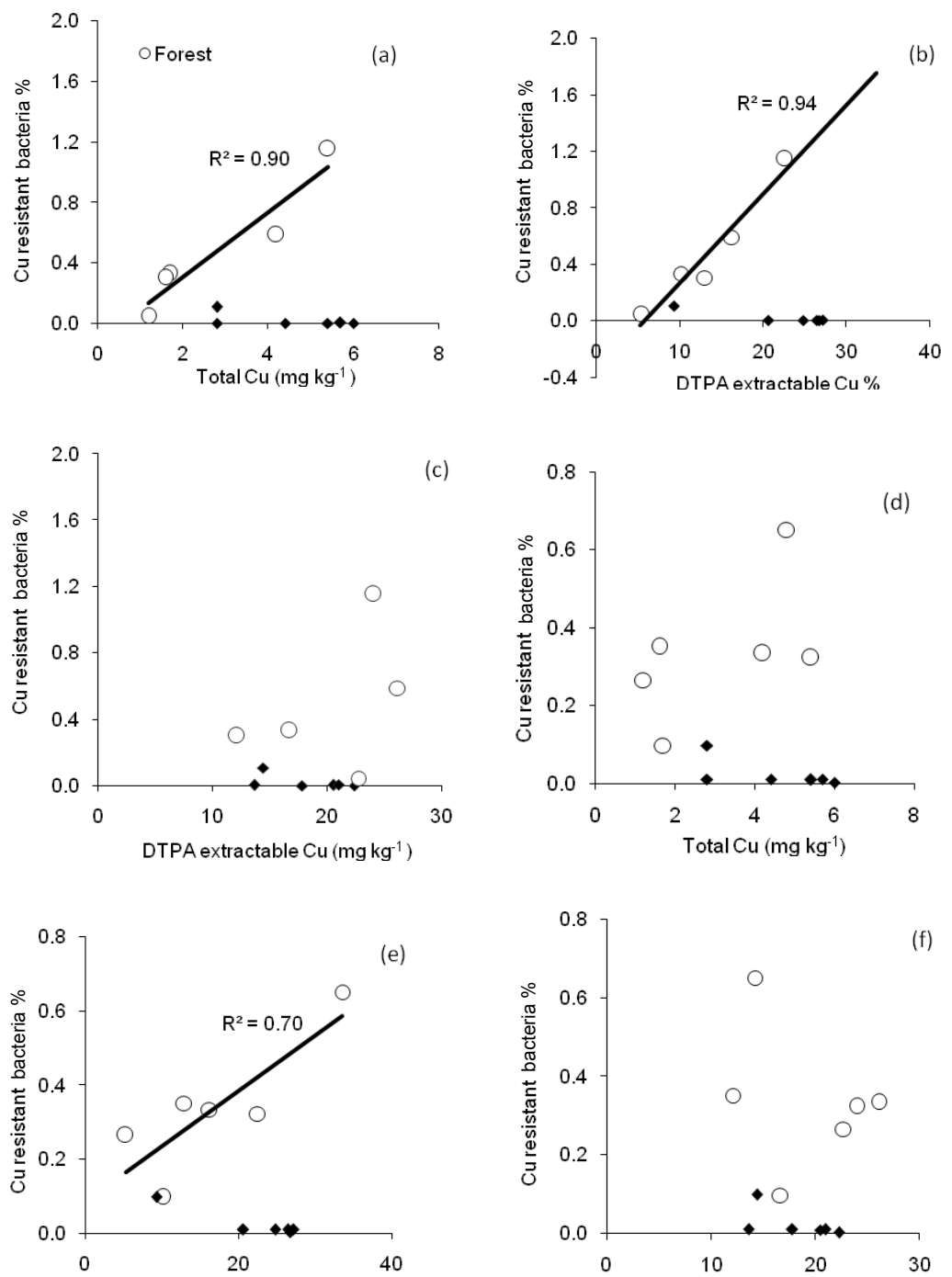

Figure 2: Relationship between $\mathrm{Cu}$ fractions in soil and percentage of $\mathrm{Cu}$ resistant bacteria $(\mathrm{n}=6)$ appeared on $\mathrm{Cu}$ amended TSA medium ( $\mathrm{a}, \mathrm{b}$ and $\mathrm{c}$ ) and PDYA medium (d, e and $\mathrm{f}$ ) 
$(\mathrm{R}=0.48, \mathrm{p}<0.05)$ and organic $\mathrm{C}(\mathrm{R}=0.49, \mathrm{p}<0.05)$. It is known that the available $\mathrm{C}$ pool supports the survival of bacteria under metal stressful conditions $\mathrm{s}^{32}$. Accordingly, limited availability of $\mathrm{C}$ in cultivated fields may also have hindered the proliferation of $\mathrm{Cu}$-resistant bacteria. Thus, the observed disparity between DTPA extractable $\mathrm{Cu}$ and $\mathrm{Cu}$-resistant bacterial populations may be accounted for by the high variability in total $\mathrm{Cu}, \mathrm{pH}$ and organic $\mathrm{C}$ between fields.

Huysman et al. ${ }^{16}$ demonstrated that $\mathrm{Cu}$ resistance in bacteria could be developed due to long-term exposure to DTPA extractable metal contents as low as $3 \mathrm{mg} \mathrm{kg}^{-1}$. Saek et al. ${ }^{18}$ also demonstrated that bacterial resistance to $\mathrm{Cu}$ increased with increasing metal content from 0.011 to $12 \mathrm{mg} \mathrm{kg}^{-1}$ soil in the exchangeable fraction. Therefore, possibility of developing resistance to $\mathrm{Cu}$ in bacteria of the studied fields cannot be overruled although it is not supported by strong correlations between the bacterial populations and $\mathrm{Cu}$ fractions.

\section{Culture media}

Suitability of four growth media to enumerate metal resistant bacteria was assessed using soils from forest and field ' $F$ ', which showed the highest DTPA extractable $\mathrm{Cu}$ content. In both fields, populations of the total and the $\mathrm{Cu}$-resistant bacteria were different between four media assessed (Table 4). It is possible to select different bacterial populations by each medium as their constituents are different. In addition, $\mathrm{Cu}$ availability may also differ between tested media. Ramamoorthy and Kushner ${ }^{36}$ studied the binding of $\mathrm{Hg}^{2+}, \mathrm{Pb}^{2+}, \mathrm{Cu}^{2+}$ and $\mathrm{Cd}^{2+}$ ions to widely used bacterial growth media and reported that the relative affinity of different media components to different ions varied with the cation studied. Colonies on agar plates consisting of TSA, PDYA and PGA media appeared after one day of incubation, whereas it took three to four days on the TSB medium. Higher percentages of $\mathrm{Cu}$-resistant bacteria were produced in PDYA and TSA plates inoculated with forest soil and on PDYA medium inoculated with the cultivated soil (Table 4). Percentage of Cu-resistant bacteria of forest soils appeared on TSA and PDYA media showed linear relationships with total $\mathrm{Cu}$ and percentage of DTPA extractable $\mathrm{Cu}$ but not with DTPA extractable $\mathrm{Cu}$ content in soil (Figures $2 \mathrm{a}$ and $2 \mathrm{~b}$ ). This may imply that $\mathrm{Cu}$ availability in TSA and PDYA media may represent the average $\mathrm{Cu}$ levels experienced by bacteria in situ. Since the fluctuation of $\mathrm{Cu}$ in the forest soil is minor, the extractable fractions of $\mathrm{Cu}$ at the time of sampling may represent average values that exist in soil. Accordingly, bacteria population appeared on these media may represent the population which is resistant to the reported $\mathrm{Cu}$ fractions. In contrast, available fractions of $\mathrm{Cu}$ may fluctuate temporally in the cultivated soil, along with the changes in soil $\mathrm{pH}$ and the organic $\mathrm{C}$ content. As a result, $\mathrm{Cu}$-resistant bacterial populations may not essentially represent those who are resistance to the $\mathrm{Cu}$ fractions reported at the time of sampling. As suggested previously ${ }^{35}$ the resistance may develop to the highest levels of $\mathrm{Cu}$ to which bacteria were exposed frequently. Therefore, linear relationships were not established between $\mathrm{Cu}$ fractions and $\mathrm{Cu}$ resistant bacterial populations of cultivated soils.

\section{CONCLUSION}

Resistance to $\mathrm{Cu}$ has developed in bacteria of the studied fields responding to the DTPA extractable $\mathrm{Cu}$ concentrations higher than $1.2 \mathrm{mg} \mathrm{kg}^{-1}$ soil. Confounding effect of soil $\mathrm{pH}$ and organic $\mathrm{C}$ was evident on the variability of $\mathrm{Cu}$ fractions and $\mathrm{Cu}$-resistant bacterial populations of the cultivated fields. In addition, SIR and $\mathrm{BN}$ of the studied fields were sensitive to $\mathrm{Cu}$. Population of $\mathrm{Cu}$-resistant bacteria did not vary over the years of cultivation but correlated with the DTPA extractable $\mathrm{Cu}$ contents. The culturable fraction of $\mathrm{Cu}$-resistant bacterial populations was enumerated by the PDYA medium better than the three other tested media. Results suggest that $\mathrm{Cu}$-resistant bacterial population could be treated as an indicator of soil quality of the studied fields if interpreted in conjunction with the variability of $\mathrm{pH}$ and organic $\mathrm{C}$.

\section{References}

1. Romkens P.F.A.M. \& Salomons W. (1998). Cd, Cu and Zn solubility in arable and forest soils: consequences of land use changes for metal mobility and risk assessment. Soil Science 163 (11): 859 - 871.

2. Zwieten L.V., Rust J., Kingston T., Merrington G. \& Morris S. (2004). Influence of $\mathrm{Cu}$ fungicide residues on occurrence of earthworms in avocado orchard soils. Science of the Total Environment 329 (1 - 3): 29 - 41.

3. Cavallaro N. \& McBride M.B. (1980). Activities of $\mathrm{Cu}$ and $\mathrm{Cd}$ in soil solution as affected by $\mathrm{pH}$. Soil Science Society of America Journal 44 (4): 729 - 733.

4. Sims J.T. (1986). Soil $\mathrm{pH}$ affects on distribution and plant availability of $\mathrm{Mn}, \mathrm{Cu}$ and $\mathrm{Zn}$. Soil Science Society of America Journal 50: 367 - 373.

5. Alva A.K., Baugh T.J., Sajwan K.S. \& Paramasiwam S. (2004). Soil pH and anion abundance affect on copper adsorption. Journal of Environmental Science and Health 39 (5/6): 903 - 910.

6. Gomes P.C., Fontes M.P.F., de Silva A.G., Mendonca E. de S. \& Netto A.R. (2001). Selectivity sequence and competitive adsorption of heavy metal by Brazilian soils. Soil Science Society of America Journal 65: 1115 - 1121.

7. Yu S., He Z.L., Huang C.Y., Chen G.C. \& Calvert D.V. (2002). Adsorption - desorption behaviour of copper at contaminated levels in red soils from China. Journal of 
Environmental Quality 31: 1129 - 1136.

8. Sauve S., Cook N., Hendershot W.H. \& McBride M. B. (1996). Linking plant tissue concentrations and soil copper pools in urban contaminated soils. Environmental Pollution 94 (2): 153 - 157.

9. Sauve S., Dumestre A., McBride M. \& Hendershot W. (1998). Derivation of soil quality criteria using predicted chemical speciation of $\mathrm{Pb}^{2+}$ and $\mathrm{Cu}^{2+}$. Environmental Toxicology and Chemistry 17 (8): 1481-1489.

10. Courchesne F., Kruyts N. \& Legrand P. (2005). Labile zinc concentration and free copper ion activity in the rhizosphere of forest soils. Environmental Toxicology and Chemistry 25 (3): 635 - 642.

11. Ehrlich H.L. (1997). Microbes and metals - Mini Review. Applied Microbiology and Biotechnology 48 (6): 687 692.

12. Baath E., Ravina M.D., Frostegard A. \& Campbell C. D. (1998). Effect of metal rich sludge amendments on the microbial community. Applied and Environmental Microbiology 64 (1): 238 - 245.

13. Nakatsu C.H., Carmosini N., Baldwin B., Beasley F., Kourtev P. \& Konopka A. (2005). Soil microbial community responses to additions of organic carbon substrates and heavy metals $(\mathrm{Pb}$ and $\mathrm{Cr})$. Applied and Environmental Microbiology 71 (12): 7679 - 7689.

14. Oorts K., Bronckaers H. \& Smolders E. (2005). Discrepancy of microbial response to elevated copper between freshly spiked and long term contaminated soils. Environmental Toxicology and Chemistry 25 (3): 845 853.

15. Yuangen Y., Campbell C.D., Clark L., Cameron C.M. \& Paterson E. (2006). Microbial indication of heavy metal contamination in urban and rural soils. Chemosphere $\mathbf{6 3}$ : 1942 - 1952.

16. Huysman M., Verstraete W. \& Brookes P.C. (1994). Effect of manuring practices and increased copper concentrations on soil microbial populations. Soil Biology and Biochemistry 26 (1): 103 - 110.

17. Yamamato H., Tatsuyama K. \& Uchima T. (1985). Fungal flora of soil polluted with copper. Soil Biology and Biochemistry 17: 785 - 790

18. Saeki K., Kunito T., Oyaizu H. \& Matsumoto S. (2002). Relationship between bacterial tolerance levels and forms of $\mathrm{Cu}$ and $\mathrm{Zn}$ in soils. Journal of Environmental Quality 31: 1570 - 1575.

19. Kalpage F.S.C.P., Mitchell B.D. \& Mitchell W.A. (1964). The mineralogy of some Ceylon soils. Clay Minerals Bulletin 5: 308 - 318.

20. Mapa R.B. (1992). Clay mineralogy of six Sri Lankan soils. Journal of the Geology Society of Sri Lanka 4:45- 47.

21. McLean E.O. (1982). Soil pH and lime requirement. In: Methods of Soil Analysis Part 2 - Chemical and Microbial Properties, Second edition (Eds. A.L. Page, R.H. Miller \& D.R. Keeny) American Society of Agronomy and Soil Science Society of America, Madison, USA.

22. Walkley A. (1946). A critical examination of a rapid method for determining organic $\mathrm{C}$ in soils - effect of variation in digestion conditions and of inorganic soil constituents. Soil Science 63: 251 - 263.
23. Sposito G., Levesque C.S., Leclaire J.P. \& Chang A.C. (1983). Trace metal chemistry in arid zone field soils amended with swage sludge. III. Effect of time on the extraction of trace metals. Soil Science Society of America Journal 47: 898 - 902.

24. Lindsay W.L. \& Norvell W.A. (1978). Development of DTPA soil test for zinc, iron, manganese and copper. Soil Science Society of America Journal 42: 421 - 428.

25. Anderson J.P. E. \& Domsch K.H. (1978). A physiological method for the quantitative measurement of microbial biomass in soils. Soil Biology and Biochemistry 10: 251 221.

26. Voroney R.P., Winter J.P. \& Begaert R. P. (1993). Soil microbial biomass $\mathrm{N}$ and C. In: Soil Sampling and Methods of Soil Analysis (Ed. M. R. Carter) pp. 277 - 286. Canadian Society of Soil Science, Lewis Publishers. 58

27. Hinda A.A. \& Lowe L.E. (1980). Application of the Berthelot reaction to the determination of ammonium $-\mathrm{N}$ in soil extracts and digests. Communication in Soil Science and Plant Analysis 11 (5): 469 - 475.

28. Boehm M.M. \& Anderson D.W. (1997). A landscape scale study of soil quality in three prairie farming systems. Soil Science Society of America Journal 61: 1147 - 1159.

29. Groffman P.M., McDowell W.H., Myers J.C. \& Merriam J. L. (2000). Soil microbial biomass and activity in tropical riparian forests. Soil Biology and Biochemistry 33 (10): $1339-1348$.

30. Ocio J.A. \& Brookes P. C. (1990). An evaluation of methods for measuring the microbial biomass in soils following recent additions of wheat straw and the characterization of the biomass that develops. Soil Biology and Biochemistry 22 (5): 685 - 694.

31. Chander K. \& Brookes P.C. (1991). Microbial biomass dynamics during the decomposition of glucose and maize in metal contaminated and non contaminated soils. Soil Biology and Biochemistry 23 (10): 917 - 925.

32 Dahlin S.\&WitterE.(1998). Can the low microbial biomass $\mathrm{C}$ to organic $\mathrm{C}$ ratio in an acid and a metal contaminated soil be explained by differences in the substrate utilization efficiency and maintenance requirements? Soil Science Society of America Journal 30 (5): 633 - 641.

33. Insam H., Hutchinson T.C. \& Reber H.H. (1996). Effect of heavy metal stress on the metabolic quotient of the soil microflora. Soil Biology and Biochemistry 28 (4/5): 691 694.

34. Lovell R.D., Jarvis S.C. \& Bardgett R.D. (1995). Soil microbial biomass and activity in long term grassland: Effects of management changes. Soil Biology and Biochemistry 27 (7): 969 - 975.

35. Viti C., Quaranta D., De Philippis Cort G., Agnelli A., Cuniglio R. \& Giovannetri L. (2007). Characterizing cultivable soil microbial communities from copper fungicide-amended olive orchard and vineyard soils. World Journal of Microbiology and Biotechnology DOI 10:1007/s11274-007-9472-x.

36. Ramamoorthy S. \& Kushner D.J. (1975). Binding of mercuric and other heavy metal ions by microbial growth media. Microbial Ecology 2 (2): 162 - 176. 